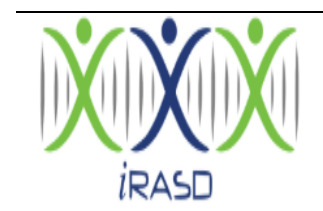

iRASD Journal of Management

Volume 2, Number 2, 2020, Pages 56 - 68

\title{
Debt Financing Management: The Modes of Debt Financing for Small and Medium-Sized Enterprises (SEMs) in Pakistan
}

Dr. Waseem Ul Hameed ${ }^{1}$, Dr. Hisham Bin Mohammad², Javed Iqbal ${ }^{3}$, Shazma Razzaq ${ }^{4}$

Dr. Nadeem Maqbool ${ }^{5}$

${ }^{1}$ Centre of Excellence for Islamic Finance and Social Equity (CEIFSE), Department of Islamic and Conventional Banking (DICB), Institute of Business, Management and Administrative Sciences (IBMAS), The Islamia University of Bahawalpur (IUB), Pakistan, Email: waseemulhameed@iub.edu.pk

${ }^{2}$ School of Economics, Finance and Banking (SEFB), Universiti Utara Malaysia (UUM), Malaysia, Email: mhisham@uum.edu.my

${ }^{3}$ Deputy Director (Audit), The Islamia University of Bahawalpur (IUB), Pakistan, Email: javediqbal2037@gmail.com

${ }^{4}$ School of Languages, Civilization, and Philosophy (SLCP), Universiti Utara Malaysia (UUM), Malaysia, Email: shazmarazzaq4@gmail.com

${ }^{5}$ Institute of Business, Management and Administrative Sciences (IBMAS), The Islamia University of Bahawalpur (IUB), Pakistan, Email: nadeemmaqbool90@yahoo.com

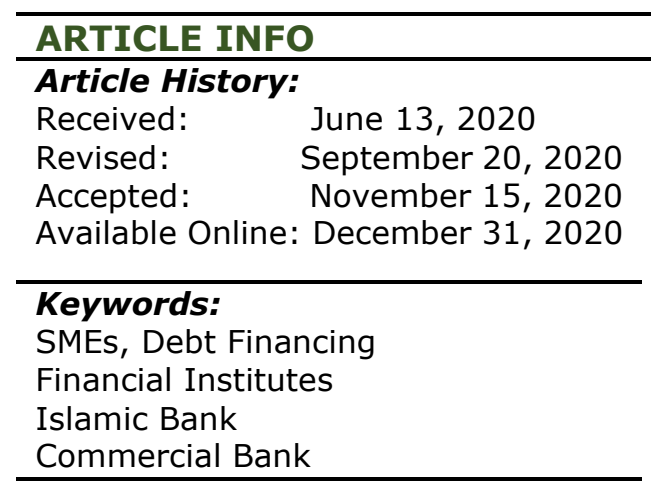

\section{ABSTRACT}

Purpose - The basic purpose of this paper is to analyze the debt financing of small and medium-sized enterprises (SMEs) in Pakistan through different modes from conventional and nonconventional (Islamic) institutes.

Design/Methodology/Approach - Data is publicly available on databases and websites about debt financing of small and medium-sized enterprises (SMEs) of Pakistan, thus data is collected from these databases and websites in the form of articles and handbooks about Pakistan.

Findings - It is found from the analysis that a lot of financing choices and modes are available for small and medium-sized enterprises (SMEs) in Pakistan. These modes are provided by both conventional and non-conventional (Islamic) financial institutes. All the debt modes are discussed in the paper. In addition, there are some drawbacks of debt financing that arises from conventional and non-conventional (Islamic) financial institutes, which alleviate small and medium-sized enterprises (SMEs) from adopting these modes

Research Limitations/Implications - Some financial institutes, especially banks, lack knowledge and information about small and medium-sized enterprises (SMEs) in Pakistan. Banks could lessen it by acting as a mediator for small and medium-sized enterprises (SMEs).

Originality/Value - This review paper's main contribution is to analyze the contribution of financial institutes in debt financing small and medium-sized enterprises (SMEs) in Pakistan. Paper discusses all the modes available for the small and medium-sized enterprises (SMEs) in Pakistan thoroughly through conventional and non-conventional (Islamic) financial institutes.

(C) 2020 The Authors, Published by iRASD. This is an Open Access article under the Creative Common Attribution Non-Commercial 4.0

Corresponding Author's Email: waseemulhameed@iub.edu.pk

\section{Introduction}

Debt finance availability for small and medium enterprises (SMEs) is a topic of important research concern to academics and around the world, an issue of excessive significance to policymakers. From Pakistan's perspective, this research has supported our understanding of the effects of policies and help and obstruct the access to funding the creditworthy SMEs in Pakistan. Small and medium enterprises (SMEs) always have the requirement of external finance 
(Tran). The availability of finance helps SMEs' growth, as is observed from current research knowledge (Adomako et al., 2021). Financial institutions in Pakistan have different structures and lending infrastructure due to which system affects SMEs' finance availability. These financial institutions are the sources of credit availability (Altaf, Hameed, Nadeem, \& Arfan, 2019; WU Hameed, 2019; Waseem Hameed, Mohammad, \& Shahar, 2018; Waseem Hameed, Nawaz, Basheer, \& Waseem, 2019; W. U. Hameed, Hussin, Azeem, Arif, \& Basheer, 2017; W. U. Hameed, Mohammad, \& Shahar, 2020a, 2020b; W. U. Hameed, Nisar, Abbas, Waqas, \& Meo, 2019; W. U. Hameed, Waseem, Sabir, \& Dahri, 2020; Razzaq, Maqbool, \& Hameed, 2019). Sources of debt finance are very important for SMEs because they provide funds for the growth and development of small and medium enterprises. Domestic banks, foreign banks, loan companies, credit co-operatives, and life insurers are debt finance sources in Pakistan. Except these, the sources of finance government of Pakistan also interest in improving small and medium enterprises (SMEs) and making policies about external finance. These sources used different modes of finance. Every institution uses specific finance modes that are collaborating with policies designed by the institution for the provision of finance in Pakistan. Different finance modes are factoring by a bank, trade credit, short term loan, personal funds, overdraft, and working capital. These are short-term modes of finance that are provided for small and medium enterprises (SMEs). Commercial paper, project finance, and long-term loan; are the extended tenure modes of finance for SMEs.

Bank is the most popular source of finance in Pakistan. Commercial banks contribute to the boost up of small and medium enterprises (SMEs) in Pakistan. Different banks provided different types of finance facilities for different sectors of SMEs. United bank limited mostly provides finance for the manufacturing sector of SMEs in Pakistan. For expansion in a unit or new machinery vehicles, MCB bank advances finance on the particular conditions for small and medium enterprises (SMEs). Standard chartered bank has many policies about financing for the textile sector in manufacturing concerns. The agriculture sector is also supported by advances to agriculturists from a bank of standard chartered. SMEs are the strong base of the economy of our country, with the development of the SMEs industry, the country's economy also goes up. That is why Islamic banking promoted the small and medium enterprises (SMEs) industry by providing facilities like finance without interest-based. Islamic banking provides facilities on contract base with the involvement of risk factor, which is managed from these agreements like Murabaha, Ijaraha, lease, and Salam. SMEs are on the way to development in the country. That's why from many years ago, the government of Pakistan focus on small and medium enterprises and put into a potential investment of finance, technology, efforts, and skills in the development of small and medium enterprises (SMEs).

\section{Literature Review}

\subsection{Small and Medium Enterprises Sector}

SMEs stand for small and medium enterprises. These are non-subsidiary and independent companies with a standard limit of employees or have an authorized capital or maintain a standard amount of revenue. This standard varies from country to country. The most followed limit in SMEs is less than 250 employees. However, some countries like America and European Union set the standard of 500 employees. In Pakistan, SMEs limit up to 250 employees or have an authorized capital of 25 million Pakistani rupees or maintain an annual sale of 250 million Pakistani rupees. In 2002, as per the presidential ordinance, the Small and Medium Enterprises Development Authority (SMEDA), as an autonomous body regulated by the federal government of Pakistan, started to regulate SMEs and ensure the growth and encouragement to facilitate SMEs("Smeda," 2013). SMEDA is a professional management structure that provides a business environment and development for SMEs. SMEDA is a policy adviser to government and business institutions under the Ministry of Industries. SMEs have great importance in the industrial development of any country. In Pakistan, SMEs constitute $90 \%$ of all the enterprises, which is enormous in number, team members more than $80 \%$ of the non-agriculture labor force, and SMEs share in the GDP of Pakistan is about $40 \%$. SMEs have lack financial and other resources, so SMEDA is working out to avoid these constraints through supporting SMEs in technical upgradation, marketing, financial, and human resource training \& development. Different types of clusters of SMEs working out in Pakistan: Textile/Apparel, Horticulture/Fruits and Vegetables, Gems, Agriculture, Fishery, Credit for Auto, Furniture, Garments and Cotton Ginning("Smeda," 2013). 


\subsection{Debt Financing}

When a Body takes a loan from a lender to pay back with interest after using the money, and another person also gives him a loan with this understanding that he will charge the interest on his money, this situation is called debt financing. Debt financing means lending money from an external source to return the principal amount within the additional decided ratio of interest. Undoubtedly, debt is adverse; this is still very helpful for newly started businesses because, initially, every business needs money for its operations. Even if we see the highly profitable firm's financial statement, there would be much debt involvement. Modes of finance for SME's are described below:

\subsubsection{Factoring by a Bank}

When a company instantly wants cash for its business, it can sell its account receivable to a factoring company so that all its debtors can recover, and the factoring company collects money from the customers. When customers are not willing to pay until the end of a contract, customers have to pay back to a factoring company with relatively high interest ("Different types of debt financing,"). Bank recovers funds from all account receivables in domestic and international trade. In this way, small companies can get debt and use it to enhance business(2020).

\subsubsection{Trade Credit}

When a small business needs debt finance for investing in a business, it can also take loans from its suppliers by understanding the terms and conditions that small businesses will pay later. Sometimes when a business goes for a startup, then it can take help from suppliers and suppliers extend the terms of payment of a loan to 90 days instead of asking for instant payment("Types of Debt financing for small business," 2001-2012)

\subsubsection{Term Loan}

It is the most well-known type of debt financing, but small business enterprises mostly use it. When small business enterprises take a loan from an external source, particular institutes with a loan require monthly payment on the principal amount, including interest. It can be challenging for small business enterprises, but they can easily practice debt financing when they really need funds for a business. From where small enterprises engage in debt financing, they usually go for bank \& credit union loans. According to another author, the loan terms can also vary from three to ten years. Interest can also be varied and mostly based on company risk profile. Assets of the company are collaterals for a bank(2004).

\subsubsection{Personal Funds}

If a business needs debts for its business, then the business owner also can get debt for business from close relatives, and with no disturbance of amount for equity in the company, the owner can quickly get debts from their peer. They return money to them with easy terms and conditions. It is flexible that there is no formal agreement.

\subsubsection{Agreement of Overdraft}

In this mode, an agreement is always decided between a bank and its business for debt financing. In this mode, the owner has limitations that he can get debt up to limit to the account which is set by the bank. If the owner's account low deposits that are not covering the amount on which he will get a loan, then the owner has to pay interest with the principal amount. And a bank charges a high-interest rate, a five percent rate plus a prime rate. It's also called "overdraft lines of credit" ("Types of Debt financing for small business," 2001-2012). 


\subsubsection{Working Capital Loan}

It is mostly used for the short term used by a business to fulfill the functional needs. Businesses need such type of debt to purchase material, marketing and support their supply chain for production purposes, and manage the cash flows internally. A business can use debt financing only when the business gives security to the bank against a loan. Companies that get such debt repay the loan regularly and maintain the proper accounts ("Financing Your Small Business,").

\subsubsection{Other Modes of Financing}

Companies issue these commercial papers as a tool of debt financing at a discount on face value. Banks and persons usually purchase commercial papers. These are substantial capital loans, and large companies move up it from a cluster of banks. One bank act as a leader among others bank. Banks expect to obtain domestic or international companies (Different types of debt financing). Those projects whose infrastructures are long and extensive, those types of projects call for equity and debt both, required a tremendous amount of money. Assets of projects can be collateral for banks, and projects generate cash flows for repayment of debts. Projects can be dams, ports, buildings \& roads (Different types of debt financing). This is also a tool of debt financing, and a company sells it for a long time, and both seller and buyer make a deal of debenture with this understanding that pays back the money at an assured interest rate to the payer (Different type of debt financing)("Different types of debt financing,"). When one firm needs debt for its business, it can get debt from other corporations to fulfill their need for debt financing (Ul-Hameed, Mohammad, \& Shahar, 2018; Ul-Hameed, Mohammad, Shahar, Aljumah, \& Azizan, 2019). But it is short term help of a company (Different type of debt financing)

\subsection{Sources of Finance \\ 2.3.1. Domestic Banks}

Domestic banks play a significant role in providing financial services to their customers ("Types of Debt financing for small business," 2001-2012). SME's are important customers for banks. Commercial banks provide debt finance to many institutions and organizations also. It can be said that domestic banks are most important for the provision of debts to SME's (Berger \& Udell, 2004).

\subsubsection{Foreign Banks}

Foreign banks also provide debt finances to the SME's and other sectors. Foreign bank's debt provision is twice as domestic banks ("Financing Your Small Business,"). Increment in the debt financing from the foreign banks is seen in the past few years as the financial services are not limited to the country's territory only ("Types of Debt financing for small business," 20012012). The role of foreign banks is important in SME's debt financing in developing nations (Perera \& Gunaratna, 2020).

\subsubsection{Trust and Mortgage; Loan Companies}

Trust, and different mortgage companies are also providing loans or debts for SME's. Their ratio is increasing day by day. Trust companies are at a decline in this sector, and loan companies provide more debts (Shutt \& Vanasse, 1999). From the year 1944 to the year 1947, trust companies' net worth begins to come down, which affected debt financing for SMEs also (Carvalho, Perdigao, \& Schechtman, 2020).

\subsubsection{Credit Co-Operatives}

Credit co-operatives also provide the debt finances to the SME's and other finance needed companies. The focus of credit co-operatives for the debts mortgage is on non-residential properties. Lending activities of credit co-operatives also include loan provision (Adil \& Jalil, 2020). Life insurance companies mainly provide life insurances, but the provision of loans or debts for SMEs is also done by insurance companies in many countries (Shutt \& Vanasse, 1999). 
Developed countries are more focused on providing debt finance by the insurance companies (Hussain, Hassan, Bakhsh, \& Abdullah, 2020). Mortgages for the security are residual and nonresidual properties of SME's. Loans provided to SME's are 192 billion dollars in 1997 only (Shutt \& Vanasse, 1999).

\subsubsection{Specialized Financial Institutions}

The specialized institutions of the country also provide debts. These institutions provide loans or debts for years and increase the industries' growth rate in countries. This is not a significant source but a good one for small businesses and industries. In many countries, this practice is increasing the trend of loan provision to SME's (Shutt \& Vanasse, 1999). Studies and research have shown that credit cards provide essential funding sources for SME's (Dayour, Adongo, \& Kimbu). Nevertheless, calculating the ratio of the loan provided by credit cards is very difficult (Geddes \& Schmidt, 2020). The difficulty of measuring the use of credit cards is because the data is not readily available. Different techniques can be used to estimate debts provided by credit cards (Shutt \& Vanasse, 1999).

\subsubsection{SME Financing Related Initiatives of Government}

Many governments also take the initiatives to provide debts to the SME's for their improvement at a national level. Different countries have managed their policies of providing credits and loans to SME's (Shutt \& Vanasse, 1999). Corporations and agencies are made for this purpose. Those specially made organizations or agencies make possible the government's direct involvement and support to SME's in the countries (Abdulai et al.).

\subsection{Debt Financing to SME's in Pakistan}

Habib Bank is providing "running finance," "cash finance," and "demand finance' for all sectors and all types of SME concerns (Hassan, Muhammad, Sarwar, \& Zaman, 2020). Providing (Min 0.5 Million-Max: 75 Million) for a maximum of 1 year. This product is a cash flow based and collateral-based. For these products, the time for loan approval is 9 days(1999).

MCB is providing "demand finance" (for BMR expansion/new units), "working capital facilities," and for all Sectors, all types of SME business concerns (Disemadi \& Shaleh, 2020). Amount (min: 0.5 million-max 75 million). Tenure of Loan is from 1 year to 5 years. These loans are Cash Flow-based, Collateral based, and Program based. For "demand finance" (for BMR expansion/new units) and "working capital facilities," Collateral requirements are Land, Building, Inventory, PGs, Current assets, etc. Time of Loan Approval-Disbursal is Max 37 days. MCB is also providing "lease financing" (vehicle/machine/tractor) for all Sectors, all types of SME business concerns. Amount (min: 0.5 million-max 75 million). Other conditions are the same as above. For "lease financing," Repayment Modes are Equal, Monthly, Quarterly, and half-yearly installments (1999).

UBL is providing "NICF/FAPE" for all Sectors and all types of SME business concerns (Qureshi \& Herani, 2011). The amount of loan is from 1 Million to 75 Million. Tenure of Loan is 1-year minimum -1-year (Renewable) maximum. This loan is Collateral Based with a Flexible Repayment Manner. The time of Disbursal is 4-5 Weeks. All UBL branches are Designated Branches for this loan. UBL is providing "NIDF" for all Sectors and all types of SME business concerns. The amount of loan is from 1 Million to 75 Million. Repayment Modes are as allowable Quarterly. Other conditions are the same as above. UBL is providing "Rice / Paddy Advances" specifically for SME's working in Rice growing Sectors/Groups and manufacturing businesses. UBL is providing "Cotton Ginners Advances," Specifically for SME's working in Cotton growing Sectors, and the type of business is manufacturing or trading (Handbook on SME Financing Products, 2008).

Askari bank is offering "running finance," "cash finance," and "term finance" generally for all products and all sectors, and all business concerns of SME'S (Bilal, Fatima, Ishtiaq, \& Azeem, 
2020). This loan amount is a Maximum of 75 Million for 1 year(Handbook on SME Financing Products, 2008).

BANK ALFALAH is offering "ALFALAH KAROBAR finance," which is a specific SME Product. BANK ALFALAH is offering "ALFALAH MILKIAT FINANCE" For Infra-structure Capacity Building, a specific SME Product, for all sectors and all SME (2020). This loan is available for 1 year and more dependents on the business(Handbook on SME Financing Products, 2008).

Bank Standard Chartered Bank Limited Offers Specific SME Product "TANA BANA," for which Targeted Sector is Textile Weavers for all manufacturing SME concerns. SME Products "KISAN CARD" for which Targeted Sector is agriculture for all SME farmers. The loan Amount ratio is (PKR 32,000-Max: PKR 125,000). It is also an Evergreen facility renewed annually, unsecured Program Based with Repayment Mode; Bi-annual markup payment. Its Average time of Loan Approval is 16 Days. SME Product offered by a bank is "AGRI DEAL," for which Targeted Sector is Dealers of Agri. Inputs, fertilizer, and pesticides; for all SME traders. The loan Amount ratio is (0.5 Million -Max: 30 Million). Other conditions are the same as the TANA BANA product. Bank offers a general Product "BUSINESS POWER" for all Sectors and all SME business concerns. The loan Amount ratio is (1 Million -Max: 20 Million). Other conditions are the same as above. Bank's other general Product is "BUSINESS INSTALMENT LOAN" for all Sectors and all SME business concerns(2020).

Habib Metropolitan Bank provides a general product for all sectors and all types of SME concerns "WORKING CAPITAL FINANCE." Its Amount of loan is from Min: 0.5 Million to Max: 2 Million. Tenure of Product is Up to 1 year, while it is a Cash flow-based and Collateral based product. Its Repayment Mode is like Monthly, Quarterly, and Bullet Repayment. The time of Loan Approval is One month. Habib Metropolitan Bank" provides a general product for all sectors and all types of SME concerns "TERM FINANCE." Its Amount of loan is from Min: 0.5 Million to Max: 2 Million. Tenure of Product is from 3.5 up to 7 years. Other conditions are the same as above(Handbook on SME Financing Products, 2008).

\subsection{Islamic Banking Based Financing to SMEs}

SMEs are one of the targeting sectors of Islamic banking. As SMEs are one of the country's most flourishing industries, Islamic banks are also making financing in SMEs (Handbook on SME Financing Products, 2008). Following are the prominent important SMEs in which Islamic banking provides financing on a priority basis: Sports, Dairy Products, Textile Products, Livestock Products and cattle farming, Light Engineering Products, Medical Equipment Products, Auto Financing Products, Biogas plants Products, Fishing Boats \& Engines Products, Furniture Industry Products, Housing Sector Products, Carpets Products, Metal Products, Leather industry Products, Edibles(2006). Islamic banking also concentrates on risk management (Handbook on SME Financing Products, 2008). There is a defined and systematic procedure to manage all the risks in the business. This process involves the following steps: identification, measurement, monitoring, and controlling. Another primary function of risk management is to consider all the following factors and ensure that all the contracts and financing comply with the Islamic shariah. These are done to eliminate the fraud and misrepresentation in contracts and financing (Handbook on SME Financing Products, 2008). Various business risks are given in Figure 1. 


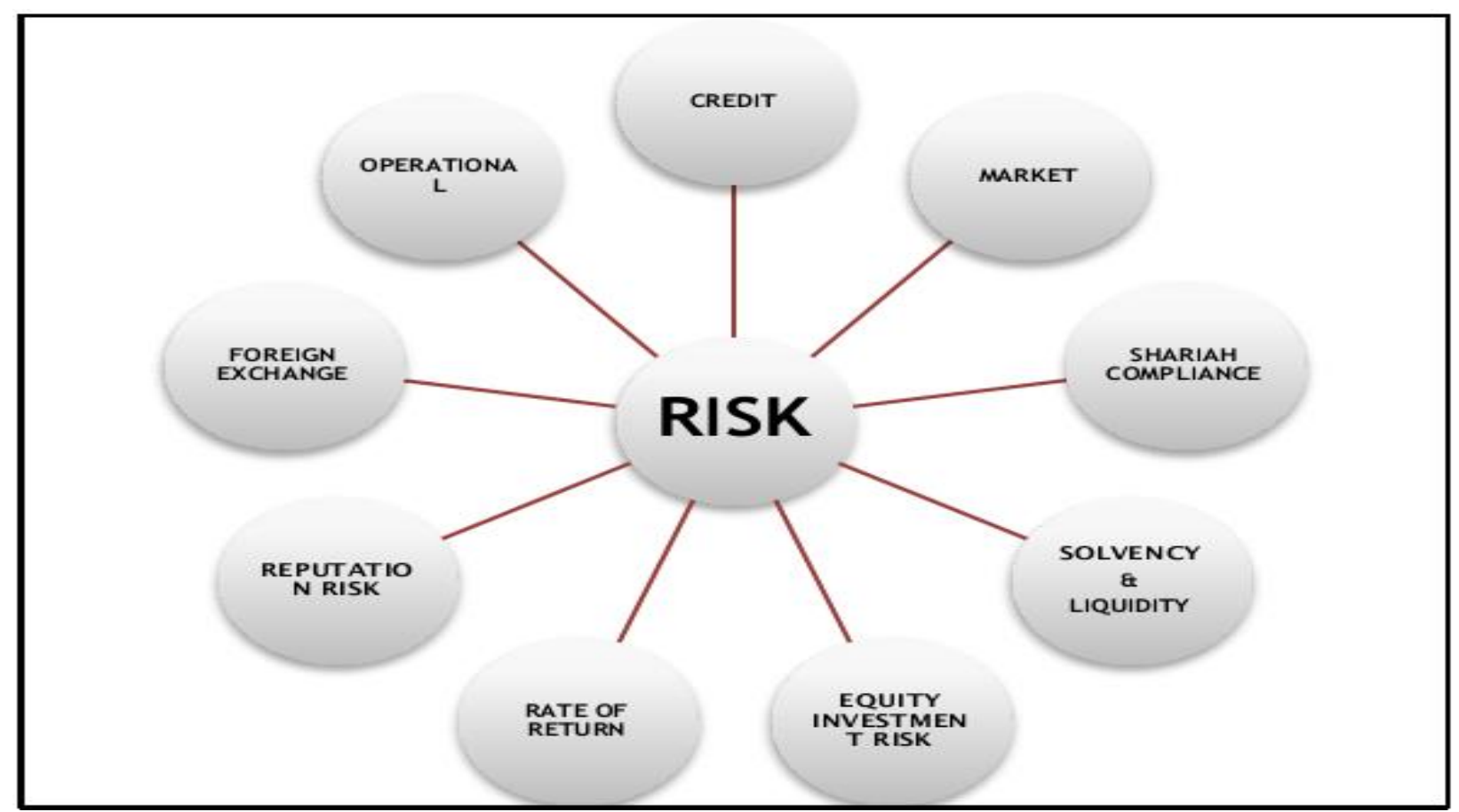

\section{Figure 1: Business Risk}

Source: Handbook on Islamic SME Financing, State Bank of Pakistan, 2008

\subsubsection{Murabaha Financing}

As charging interest in Islam is prohibited, charging profits on a product's sales is allowed by Islam (Muhamad, Ismail, Rahim, \& Ahmad, 2020). This term of financing is used in which a profit is charged on the sale of the product. Therefore, this is also based on sale-based transactions. In this term, bank-purchases goods or commodities on customer demand and sells to the customers on the amount of purchase price plus profit. The customer pays the price in the following three ways, in installments, at the spot or at the time of sale, or in a lump sum after a period of time. This financing model has a full structure in which a customer asked a bank to purchase sudden goods through applications and promise to pay the price of goods to a bank. In Murabaha financing, the bank also demands security to secure the risk that the customers will not terminate the contract (Handbook on Islamic SME Financing, 2008). Following types of securities are asked from a customer, personal guarantees, lien on deposits, pledge of goods and marketable securities, Mortgage charge on movable and immovable properties(2020). Murabaha Financing is given in Figure 2.

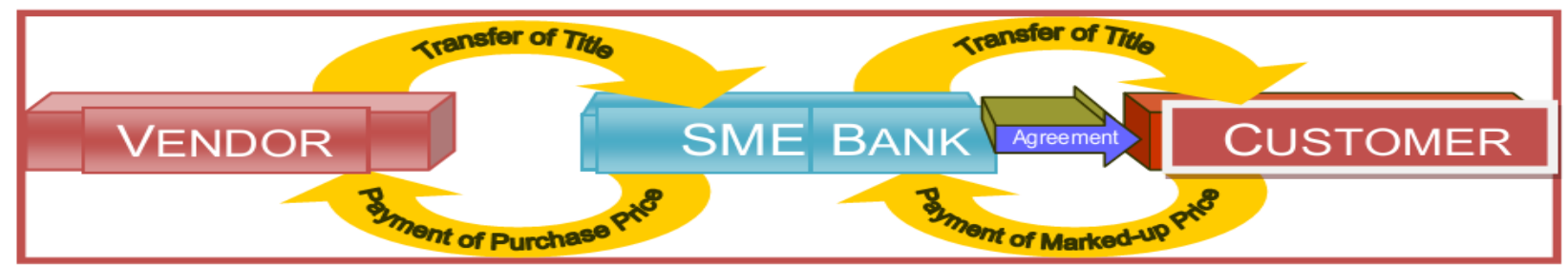

\section{Figure 2: Murabaha Financing}

Source: Handbook on Islamic SME Financing, State Bank of Pakistan, 2008

There are six main types of agreement which are essential to avail Murabaha financing, Master Murabaha Financing Agreement (MMFA), Agency Agreement, Order form, Murabaha Agreement (Declaration), Demand Promissory Note, and Payment Schedule(Handbook on Islamic SME Financing, 2008).

\subsubsection{Ijaraha Base Financing}

It is the type of financing in which a bank transfers an asset to its customer at an agreed consideration for an agreed period of time. There are some terms and conditions that the asset 
should have some value, quantity, and identification(2020). It is the type of lease in which two or more parties are involved. There are two main parties' lessee and the lessor. Lessor is the owner of the assets that lease its asset to the lessee, which takes it on lease and uses it for a period of time that is liable for the asset's wear and tear and its misuse or damage(2020).

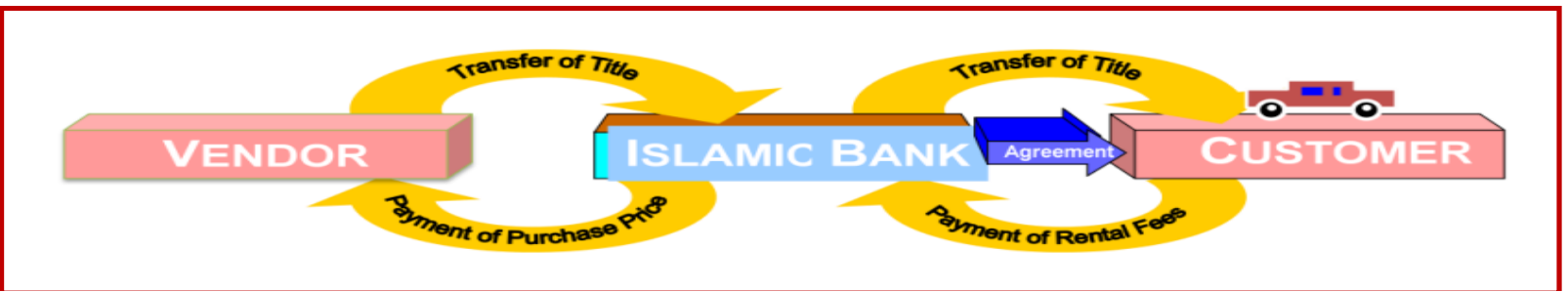

Figure 3. Ijaraha Base Financing

Source: Handbook on Islamic SME Financing, State Bank of Pakistan, 2008

There are several documents required to acquire this financing from the banks. Following are required documents: Letter of Request, Lease Application Form, Credit Memorandum, Offer Letter, Acceptance, Undertaking to Purchase Leased Asset, Lease Agreement, and Letter of Continuity, etc. (Handbook on Islamic SME Financing, 2008).

In this type of financing, the supply of goods is done on some future date, whereas the price payment is paid at the spot. The bank acts as-Salam and purchases goods at a future date for trade and benefits from low prices, as the Salam prices are less than cash sales (Handbook on Islamic SME Financing, 2008). The bank can also sell the Salam on the same terms and conditions to others, this is called parallel Salam. There are few sectors in which Salam based financing can consider as good financing(Handbook on Islamic SME Financing, 2008).

It is the joint ownership of property in which one partner promises to purchase others' equity share until all the equity is transferred to that partner. In it, the bank and customer act as joint ownership in which the customer purchases all the equity from the bank. Diminishing Musharaka is mostly done in fixed assets like House financing, Car Financing, Plant and machinery financing, Factory/Building financing, Agriculture land financing, and All other fixed Assets(Handbook on Islamic SME Financing, 2008). The primary transaction starts when a customer approaches the bank for financing. Then the bank enters into joint ownership and purchases the fixed asset for the customer. In this, the bank charges rent until the customer purchases the entire equity. When the customer purchased all the equity share of the fixed assets, the bank transfers the property ownership to the customer.

Following documents are prepared to complete diminishing Musharaka financing, Musharaka Agreement, Payment Agreement, Undertaking to purchase Musharaka Units, Undertaking to Sell Musharaka Units, Unit Sale Receipt(Handbook on Islamic SME Financing, 2008).

\subsection{Drawback of Debt Financing to SMEs}

Debt financing is providing the business with liquidity requirements to manage its daily operations \& working capital needs and presents some disadvantages to SMEs. A fixed monthly payment of principal and interest is the highest disadvantage of debt financing to SMEs. Several penalties are lien by a provider of debt on late payment or non-payment such as late charges, possession of the collateral, or early and full loan payment. The availability of debt financing is often limited to establish businesses is another disadvantage linked to SMEs finance. It can be challenging for undeveloped businesses to obtain loans due to security's non-availability because lenders mainly pursue security for their funds to lend.

Short-term debt finance may only meet the working capital or immediate business needs of SMEs, but they cannot overhaul any long-term plans that required huge capital, more considerable repayment periods, and high risk. The main problem with long-term debt financing agreements is that it usually holds many restricting sections and agreements, which also include the scope of business processes that the company is allowed to involve in, capital and administration structure restrictions, etc. Before giving a loan by Commercial banks, they may 
require a new SMEs business's pledging asset as security. If a business goes in loss/under, SMEs will lose their assets. If SMEs move to debt finance, they are running towards the risk of bankruptcy(Handbook on Islamic SME Financing).

Summary of the drawback of Debt finance is as below:

- Repayment

- High rates

- Impacts your credit rating

- Cash and collateral

\section{Methodology}

The current research deployed a quantitative research approach. In addition, a crosssectional design was employed. In this research design, the association between variables is determined employing statistical procedures. Thus, the current study determined the relationship between debt financing and SMEs performance. Therefore, this study developed one hypothesis based on the literature review presented in section 2. The hypothesis of the study is; debt financing has a positive effect on SMEs performance. To test this hypothesis, data were collected from SMEs' employees in Pakistan by using a survey questionnaire. 300 questionnaires were distributed among the employees of SMEs, and 176 valid responses were received.

\section{Data Analysis and Findings}

Data statistics are given in Table 1. It is clear from Table 1 that data is free from missing values and outlier. Furthermore, data is normal. Hence, the data is accurate to proceed with further analysis.

\section{Table 1}

\section{Data Statistics}

\begin{tabular}{lccccccccc}
\hline & No. & Missing & Mean & Median & Min & Max & STDEV & Kurtosis & Skewness \\
\hline DF1 & 1 & 0 & 3.397 & 4 & 1 & 7 & 2.116 & -1.182 & 0.288 \\
DF2 & 2 & 0 & 3.371 & 4 & 1 & 7 & 1.959 & -1.137 & 0.233 \\
DF3 & 3 & 0 & 2.974 & 2 & 1 & 7 & 2.147 & -0.628 & 0.854 \\
DF4 & 4 & 0 & 2.834 & 2 & 1 & 7 & 2.2 & -0.652 & 0.884 \\
DF5 & 5 & 0 & 3.033 & 2 & 1 & 7 & 2.17 & -0.742 & 0.798 \\
DF6 & 6 & 0 & 2.96 & 2 & 1 & 7 & 2.081 & -0.563 & 0.833 \\
DF7 & 7 & 0 & 2.894 & 2 & 1 & 7 & 2.328 & -0.836 & 0.877 \\
DF8 & 8 & 0 & 2.775 & 2 & 1 & 7 & 2.085 & -0.257 & 1.034 \\
DF9 & 9 & 0 & 2.967 & 2 & 1 & 7 & 1.889 & -0.288 & 0.822 \\
DF10 & 10 & 0 & 2.868 & 2 & 1 & 7 & 1.893 & -0.065 & 0.938 \\
SMEs1 & 11 & 0 & 2.874 & 2 & 1 & 7 & 2.101 & -0.493 & 0.904 \\
SMEs2 & 12 & 0 & 2.907 & 2 & 1 & 7 & 2.001 & -0.398 & 0.86 \\
SMEs3 & 13 & 0 & 2.947 & 2 & 1 & 7 & 2.21 & -0.743 & 0.83 \\
SMEs4 & 14 & 0 & 2.828 & 1 & 1 & 7 & 2.324 & -0.775 & 0.902 \\
SMEs5 & 15 & 0 & 2.795 & 2 & 1 & 7 & 2.085 & -0.276 & 1.029 \\
SMEs6 & 16 & 0 & 2.934 & 2 & 1 & 7 & 2.201 & -0.57 & 0.985 \\
SMEs7 & 17 & 0 & 3.523 & 4 & 1 & 6 & 1.552 & -1.13 & 0.069 \\
\hline
\end{tabular}

Data analysis is started by using the Partial Least Square (PLS). It is one of the most popular analysis tools (Hameed, Haseeb, Iqbal, Mihardjo, \& Jermsittiparsert, 2020; Hameed, Nisar, \& Wu, 2020). In the first part of data analysis, factor loading was examined, shown in Table 2. All the items have factor loadings above 0.5. The measurement model in Figure 4 also shows the factors loadings for all items. 


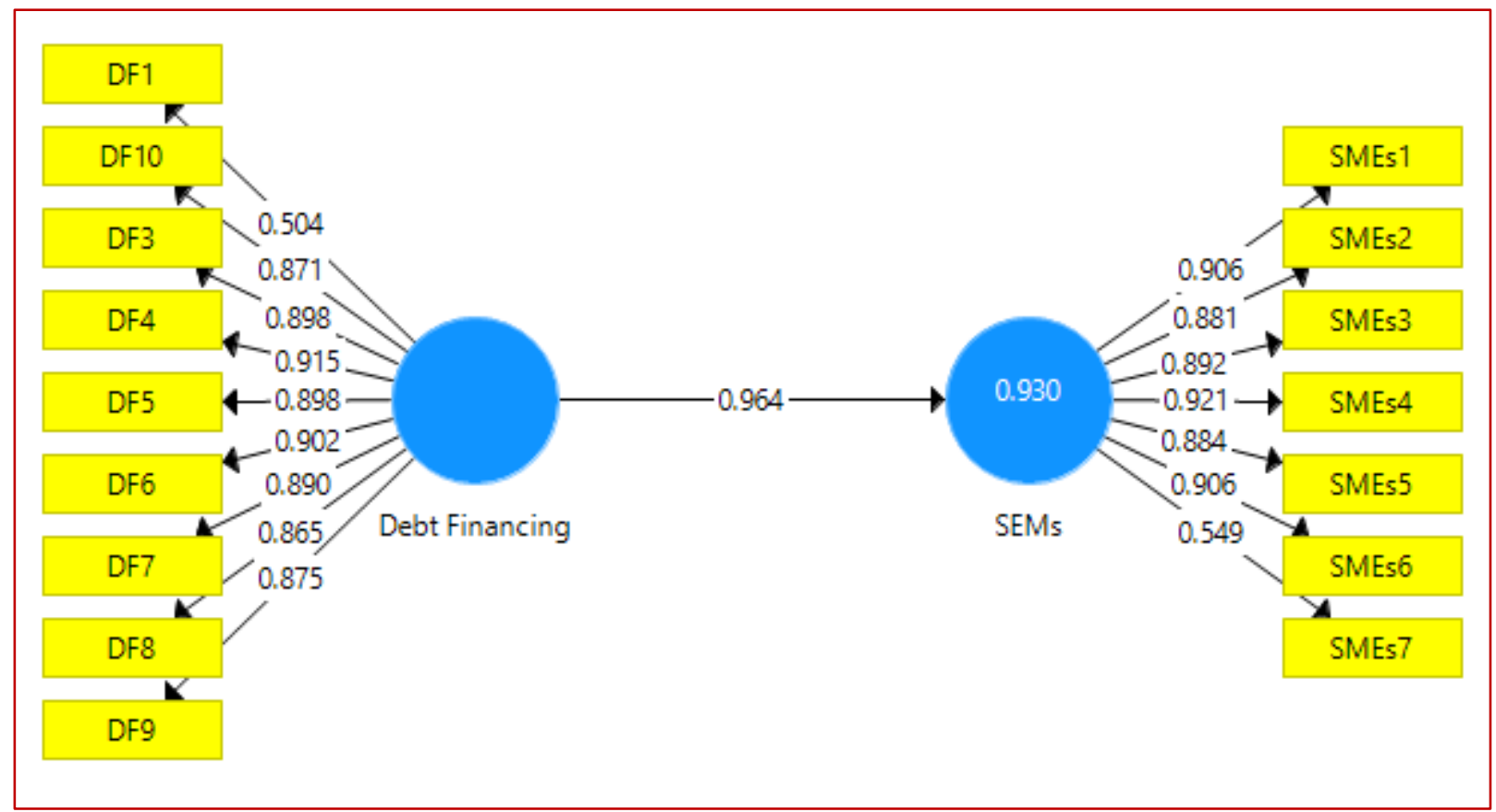

Figure 4: Measurement Model

Table 2

Factor Loadings

\begin{tabular}{lcc}
\hline & Debt Financing & SEMs \\
DF1 & 0.504 & \\
DF10 & 0.871 & \\
DF3 & 0.898 & \\
DF4 & 0.915 & \\
DF5 & 0.898 & \\
DF6 & 0.902 & \\
DF7 & 0.89 & \\
DF8 & 0.865 & \\
DF9 & 0.875 & 0.906 \\
SMEs1 & & 0.881 \\
SMEs2 & & 0.892 \\
SMEs3 & & 0.921 \\
SMEs4 & & 0.884 \\
SMEs5 & & 0.906 \\
SMEs6 & & 0.549 \\
SMEs7 & & \\
\hline
\end{tabular}

Composite reliability is also examined for debt financing and SMEs, which is given in Table 3. It shows that composite reliability is above 0.7 . Furthermore, the average variance extracted should also be above 0.5. Table 3 shows that all variables have average variance extracted above 0.5 . Finally, discriminant validity is given in Table 4 by using the cross-loadings.

\section{Table 3}

Reliability and Convergent Validity

\begin{tabular}{lcccc}
\hline & Cronbach's Alpha & rho_A & Composite Reliability & Average Variance \\
\hline Debt Financing & 0.951 & 0.96 & 0.96 & 0.731 \\
SEMs & 0.936 & 0.951 & 0.95 & 0.735 \\
\hline
\end{tabular}

After the measurement model, the current study used a structural model to test the relationship between debt financing and SMEs. The effect of debt financing was examined on SMEs performance. The structural model is given in Figure 5, and the results are given in Table 5. It is found that the t-value is above 1.96. Thus, the hypothesis is supported, and the beta value is positive. It shows that debt financing has a positive effect on SMEs performance. An increase in debt financing increases the SEMs performance.

\section{Table 4}




\section{Cross-Loadings}

\begin{tabular}{lcc}
\hline & Debt Financing & SEMs \\
\hline DF1 & 0.504 & 0.404 \\
DF10 & 0.871 & 0.844 \\
DF3 & 0.898 & 0.865 \\
DF4 & 0.915 & 0.865 \\
DF5 & 0.898 & 0.854 \\
DF6 & 0.902 & 0.833 \\
DF7 & 0.89 & 0.793 \\
DF8 & 0.865 & 0.842 \\
DF9 & 0.875 & 0.85 \\
SMEs1 & 0.862 & 0.906 \\
SMEs2 & 0.857 & 0.881 \\
SMEs3 & 0.872 & 0.892 \\
SMEs4 & 0.896 & 0.921 \\
SMEs5 & 0.805 & 0.884 \\
SMEs6 & 0.85 & 0.906 \\
SMEs7 & 0.485 & 0.549 \\
\hline
\end{tabular}

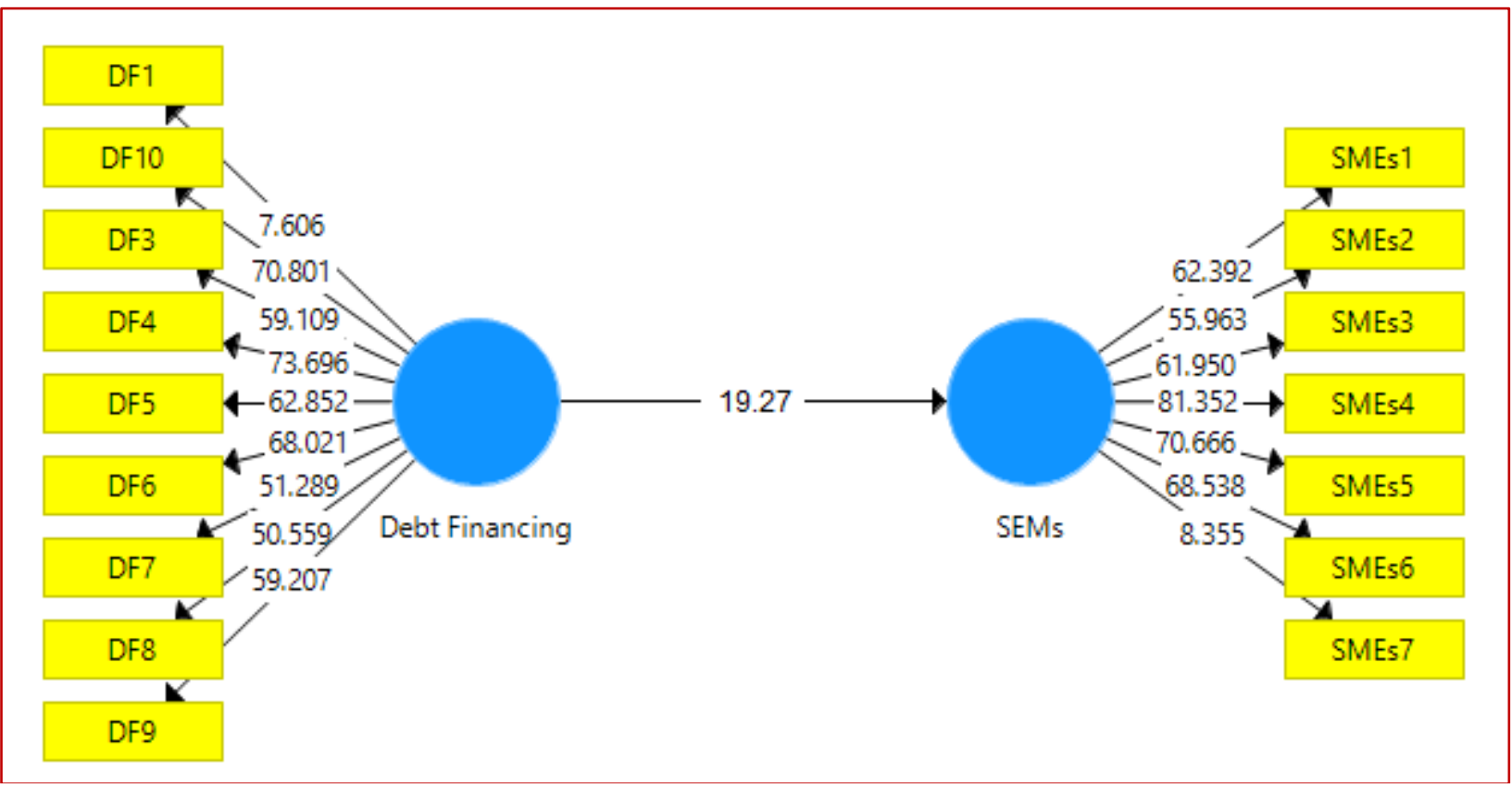

Figure 5: Structural Model

\section{Table 5}

\section{Direct Effect Results}

\begin{tabular}{|c|c|c|c|c|c|}
\hline & $\begin{array}{c}\text { Original } \\
\text { Sample } \\
\text { (0) }\end{array}$ & $\begin{array}{l}\text { Sample } \\
\text { Mean } \\
\text { (M) }\end{array}$ & $\begin{array}{l}\text { Standard } \\
\text { Deviation } \\
\text { (STDEV) }\end{array}$ & $\begin{array}{c}\text { T Statistics } \\
(\mid \text { O/STDEV|) }\end{array}$ & P Values \\
\hline Debt Financing $->$ SEMs & 0.964 & 0.964 & 0.05 & 19.27 & 0.000 \\
\hline
\end{tabular}

\section{Conclusion and Recommendations}

In this review paper, research shows that debt financing supports small and medium enterprises with different financing instruments. Small and medium enterprises have a significant contribution to the economic growth of Pakistan. It is contributed to GDP, employment rate, and industrial growth. Finance is like blood in any type of business. So, small and medium enterprises need debt finance for their running operations because the equity finance ratio is low at a small business level. There are different sources of finance established like financial institutions and banks to fulfill the need for financing. These financial institutions and banks provide different tools or policies of financing for small and medium enterprises. Small and medium enterprises can avail themselves of the different financing modes like factoring by a bank, trade credit, three-term loans, personal funds, working capital loans, over drafting 
agreement, commercial papers, project financing, and debentures short and medium-term need of debt financing. In

Pakistan, banks are the most useable source of financing, but it is based on interest, which is prohibited in Islam's religion, so some religious businessman feels hesitation in debt financing through the banking system. Then the concept of Islamic banking in debt financing provides the solution for that religious businessman. Islamic banking is asset base system and has mutual contracts for financing. There are different contracts like Murabaha financing, Ijaraha financing, lease documents, salaam base financing, and diminishing Musharaka provide shortand long-term financing for small and medium enterprises. There is no doubt that there are some limitations for debt financing like interest payment, labiality to payment, security against a loan, etc. However, business always relies on financing, so short-term loans contributed to business operations and liability from time to time pay off, and liquidity position can be bettered with the help of short-term loans. That's why short-term debt financing beneficial for small and medium enterprises.

Small and medium enterprises should go to medium- and long-term debt financing when the small business grows to a considerable business or corporate level. Small and medium enterprises influence by modes of debt financing in the growth of Pakistan's business and industrial sector. They can also go for equity finance if they have enough resources to increase shareholders' wealth and if the business is growing day-by-day. But equity finance is suitable if the business/product life cycle is more extensive, and debt finance is suitable when the business/product life cycle is smaller.

\section{Acknowledgment}

We want to acknowledge Muhammad Atif Sattar and Ambreen Kausar's serious efforts for providing us valuable instructions to produce this research.

\section{References}

Abdulai, A.-F., Anwar, K., Abdullah, A., Murphy, L., Woldie, A., Thomas, B., \& Tarling, C. AMI Conference 2017 Best Academic Paper A Comparative Study of Financial Entrepreneurship in Ghana, Pakistan and Yemen. 4 A Comparative Study of Financial Entrepreneurship in Ghana, Pakistan and Yemen, 4.

Adil, F., \& Jalil, A. (2020). Determining the Financial Inclusion Output of Banking Sector of Pakistan-Supply-Side Analysis. Economies, 8(2), 42.

Adomako, S., Ahsan, M., Amankwah-Amoah, J., Danso, A., Kesse, K., \& Frimpong, K. (2021). Corruption and SME Growth: The Role of Institutional Networking and Financial Slack. Journal of Institutional Economics.

Akram, R., \& Tahir, A. (2020). ANALYZING FINANCIAL PERFORMANCE OF ISLAMIC AND CONVENTIONAL BANKS OF PAKISTAN: A COMPARATIVE STUDY. International Journal of Business Reflections, 1(2).

Berger, A. N., \& Udell, G. F. (2004). A More Complete Conceptual Framework for SME Finance. Paper presented at the Small and Medium Enterprises: Overcoming Growth Constraints.

Bilal, M., Fatima, S., Ishtiaq, M., \& Azeem, H. M. (2020). Factors affecting the choice of Islamic banking by SMEs in Pakistan: Implications for Islamic banks' corporate governance. Pakistan Journal of Commerce and Social Sciences (PJCSS), 14(1), 255-272.

Carvalho, C., Perdigao, B., \& Schechtman, R. (2020). When in Rome: Lending to small and medium enterprises by foreign and domestic banks.

Dayour, F., Adongo, C. A., \& Kimbu, A. N. (2020). Insurance uptake among small and mediumsized tourism and hospitality enterprises in a resource-scarce environment. Tourism management perspectives, 34, 100674.

Different types of debt financing. http://articles.maxabout.com/business-finance/differenttypes-of-debt-financing/article-6730. $\quad$ Retrieved from http://articles.maxabout.com/business-finance/different-types-of-debtfinancing/article-6730

Disemadi, H. S., \& Shaleh, A. I. (2020). Banking credit restructuring policy amid COVID-19 pandemic in Indonesia. Jurnal Inovasi Ekonomi, 5(02). 
Fatima, M., \& Izhar, Z. (2020). HRM Practices and Organizational Innovation: A Comparative Study of Manufacturing and Service Sector of Pakistan. Review of Integrative Business and Economics Research, 9, 309-332.

Financing Your Small Business. Score, Counselor to America's small business, 20.

Geddes, A., \& Schmidt, T. S. (2020). Integrating finance into the multi-level perspective: Technology niche-finance regime interactions and financial policy interventions. Research Policy, 49(6), 103985.

HAMID, K., \&, A. (2006). Financing the Small and Medium Scale Enterprises in Faisalabad (Pakistan). JOURNAL OF AGRICULTURE \&SOCIAL SCIENCES, 2(2), 106-109.

Handbook on Islamic SME Financing. (2008). Retrieved from

Handbook on SME Financing Products. (2008). Retrieved from

Hassan, J., Muhammad, N., Sarwar, B., \& Zaman, N. U. (2020). Sustainable Development through Financial Inclusion: The Use of Financial Services and Barriers in QuettaPakistan. European Online Journal of Natural and Social Sciences, 9(4), pp. 691-707.

Hussain, S., Hassan, A. A. G., Bakhsh, A., \& Abdullah, M. (2020). The impact of cash holding, and exchange rate volatility on the firm's financial performance of all manufacturing sector in Pakistan.

Muhamad, S. N., Ismail, W. N. S. W., Rahim, N. A. A. A., \& Ahmad, S. (2020). Islamic Financing for Small Medium Enterprises: Challenges and Opportunities. Global Business Management Review, 12(2), 50-64.

Perera, A., \& Gunaratna, A. (2020). Interrelations between mobile banking service quality attributes, customer satisfaction and customer loyalty in domestic commercial banks in Sri Lanka.

Qureshi, J., \& Herani, G. M. (2011). The role of small and medium-size enterprises (SMEs) in the socio-economic stability of Karachi.

Reyad, S., Chinnasamy, G., Madbouly, A., Badawi, S., \& Musleh, A. (2020). Mixed Method Approach to Assess the Effectiveness of Risk Management and Corporate Governance: A Case of Islamic Banks in Oman. Paper presented at the 20th European Conference on Research Methodology for Business and Management Studies: ECRM 2020.

Shutt, T., \& Vanasse, P. (1999). SOURCES OF SME BUSINESS DEBT FINANCING IN ATLANTIC CANADA. The Current Market for Small Business Financing, Industry Canada.

Siddique, M. A., Haq, M., \& Rahim, M. (2020). The Impact of the Islamic Banking Industry on Economic Growth and Poverty Reduction in Pakistan. In Enhancing Financial Inclusion through Islamic Finance, Volume II (pp. 259-279): Springer.

Smeda. (2013). www. smeda.org/.

Suzuki, Y., \& Miah, M. D. (2020). Shari'ah-compliant benchmark and Shari'ah-based "raf'alharaj" benchmark on prohibition of riba. International Journal of Islamic and Middle Eastern Finance and Management.

Tran, A. H. The impact of bank credit accessibility of small and medium enterprises in Ho Chi Minh city, Vietnam.

Types of Debt financing for small business. (2001-2012). National Federation of Independent Business.

Xue-Mei, S., Jun-Jie, W., \& Jin-Qing, N. (2020). Tolerance is the Foundation of Success, Profits are the Bond of Relationship: Case Study on Recognition of Interest Income in Income Discount Contract. DEStech Transactions on Social Science, Education and Human Science(icssm). 